\title{
Root Fungus Floras in Relation to Growth of Strawberry Plants in Pasteurized Soil in the Field
}

\author{
Tsuneo WATANABE* and Shoji INOUE** \\ 渡辺恒雄*・井上昭司**：畑の一部に入れた病原菌非污染土壤での \\ イチゴの生育と根部の系状菌相
}

\begin{abstract}
Penicillium spp. were predominant among 28 fungus genera recovered from the roots of the strawberry plants grown in the potted pasteurized soil set in the field, whereas Rhizoctonia and Fusarium spp. dominant among 30 genera from the roots in the potted natural soil. Increased growth of the plants in the former soil as compared with the growth in the latter about 130 days after transplanting may be attributable to the reduction of the root damage due to potential soilborne pathogens including Rhizoctonia solani by the antagonism of Penicillium spp.
\end{abstract}

(Received April 21, 1980)

\section{Introduction}

Strawberry plants grown in the root rot soil that were sterilized each year just before the runners were struck, consistently developed visually flawless roots, whereas those in unsterilized soil were very much stunted and root-rotted ${ }^{3,4}$.

Other various crops grown in sterilized soils are also better in growth, and less in the occurrence of soilborne diseases than those in unsterilized field soil. However, in completely sterilized soil, a biological vacuum was created in which contaminated pathogens often caused great crop loss ${ }^{5}$. In addition, certain plants are so sensitive to toxic substances produced from some soils when heated ${ }^{5)}$. Thus, use of partially sterilized soil in which soilborne pathogens were killed chemically or by aerated steam has been recommended to escape such hazards ${ }^{1}$. Furthermore, complete sterilization of soil in a largescale is laborious, non-econmical, and technically difficult.

Microbiological changes in the roots of strawberry seedlings by soil sterilization have been studied, especially with special reference to the population of certain bacterial groups with the respective nutritional requirements ${ }^{4,6,14)}$, but the fungus floras were not intensively studied.

The purpose of this investigation was to compare the growth of strawberry plants in potted and paper-bagged pasteurized or natural soil set in the field under natural environmental conditions, to study the fungus floras associated with the roots of these

* National Institute of Agricultural Sciences, Yatabe, Ibaraki 305, Japan 農業技術研究所

** The Sericultural Experiment Station, Kansai Branch, Ayabe, Kyoto 623, Japan 委釆試験場関西 支場 
seedlings, and the interactions of candidate antagonistic fungi from the pasteurized soil and the test organisms in dual culture. A preliminary report has been published ${ }^{12}$.

\section{Materials and Methods}

Virus-free seedlings of strawberry (Fragaria chiloensis Duch. var. ananassa Bailey, 'Donner') obtained from Saitama Horticulture Experiment Station were grown for nearly 10 months in the field of the Institute at Nishigahara without past history of strawberry cultivation before the experiments were started. Newly-developed runner plants unrooted or with root tips just showing almost in the similar age were struck in the respective potted (15-cm clay pot) or paper-bagged $(21.6 \times 21.6 \mathrm{~cm})$ one-kg soil set randomly in the field under natural conditions. Pasteurized soil was prepared by storing soil autoclaved at $100 \mathrm{C}$ for $4 \mathrm{hr}$ in a wooden box $(631 \times 388 \times 456 \mathrm{~cm})$ with metallic foil used for keeping processed tea. After storage, the wooden box was kept open to contaminate airborne soil fungi for 20 days under the greenhouse conditions and closed until use. The runners struck in the respective pots were watered daily during early 50 days, but left under natural environmental conditions afterwards.

Temperatures during experiments ranged from 12.5 to $35.5 \mathrm{C}$, averaging $23.7 \mathrm{C}$ in May to October, 1977, and from 10.3 to $37.2 \mathrm{C}$, averaging $24.9 \mathrm{C}$ in June to October, 1978 .

Experiments were conducted for two years using the potted soil in 1977, and the paperbagged soil in 1978.

To study the fungus floras associated with strawberry roots, root segments (4-mm long) were dissected from random roots, washed in running tap water for over $2 \mathrm{hr}$, blotted, and placed without surface sterilization on water agar in plates. Hyphal tips, one or two tips per segment were selected at random from the fungal growth from each segment after incubation for 1 to 3 days at 20 and $25 \mathrm{C}$, for pure culture.

The fungus floras in unsterilized, or autoclaved Nishigahara field soil were studied by isolating fungi directly from the hyphae grown from soil particles placed on water agar plates for each sample. Hyphal tips were selected 'at random after 1 to 2 days of incubation at $20 \mathrm{C}$.

To study antagonism of candidate antagonists to the test organisms, potato-dextrose agar (PDA) plates were inoculated with mycelial plug $(0.4 \mathrm{~cm}$ diam) from 1-2-day old PDA cultures or by inoculating spore masses from the respective PD broth cultures with a needle. The candidate antagonists were usually seeded first, incubated $0-3$ days at $28 \mathrm{C}$, and then the plugs $(0.4 \mathrm{~cm}$ diam) containing test organisms were placed $2 \mathrm{~cm}$ apart from the edge of the colony of the candidate antagonist tested. As test organisms, isolates of Rhizoctonia solani Kühn (78-2107) and Pythium splendens Braun (Ichigo no. 192, ATCC 36444) were selected among several isolates tested from the strawberry root isolates in this study or the previous work ${ }^{13)}$ on the basis of swift and homogeneous mycelial growth. As candidate antagonists, 18 isolates of Penicillium spp., two isolates of Trichoderma spp. and one isolate of Cunninghamella echinulata were tested.

Inhibition of the growth of test organisms in dual culture was assessed by the percentage inhibition of radial growth rate $[100 ; \times$ (radial growth rate in single culture - radial growth rate in dual culture)/ radial growth rate in single culture], and the width of the zone of inhibition formed in dual culure. 


\section{Results}

\section{Fungus floras of field soil and pasteurized soil}

Thirty-six fungus genera were identified among a total of 869 isolates obtained from the unsterilized field soil, except 20 isolates of unknowns. The dominant fungi and their respective isolation frequencies (\%) were Mortierella (22.9), Fusarium (19.4), Humicola (10.8), Penicillium (8.4), Gliocladium (7.5), Trichoderma (5.9), Chaetomium (4.9), and Pythium (4.7) in the descending order. Other genera recovered were alphabetically Circinella, Cunninghamella, Mucor, Thamnidium, Zygorrhynchus in Phycomycetes, and Alternaria, Aspergillus, Botryotrichum, Cephalosporium, Coniothyrium, Cylindrocarpon, Cladorrhinum, Histoplasma, Macrophomina, Monilia, Monocillium, Myrothecium, Oedocephalum, Papulaspora, Phoma, Pithomyces, Pyrenochaeta, Sarcinella, Stemphylium, Trichocladium, Trichurus, Verticillium, and Volutella in Fungi Imperfecti.

Fungi were not recoverable from the treated soil soon after autoclaving, but after storage for 21,121 , and 267 days in the wooden box, a total of eight genera were recovered except three isolates of unknowns. The dominant genera were Trichoderma, Cunninghamella, Monilia, and Penicillium with isolation frequencies of $7.8-37.3 \%$ in samples stored for 21 days, but the former three genera were gradually replaced by Penicillium spp. in dominacy (Fig. 1). The other genera recovered were Alternaria, Aspergillus, Fusarium, and Gliocladium. It was not determined whether these fungi survived in the autoclaved soil, or were airborne contaminants.

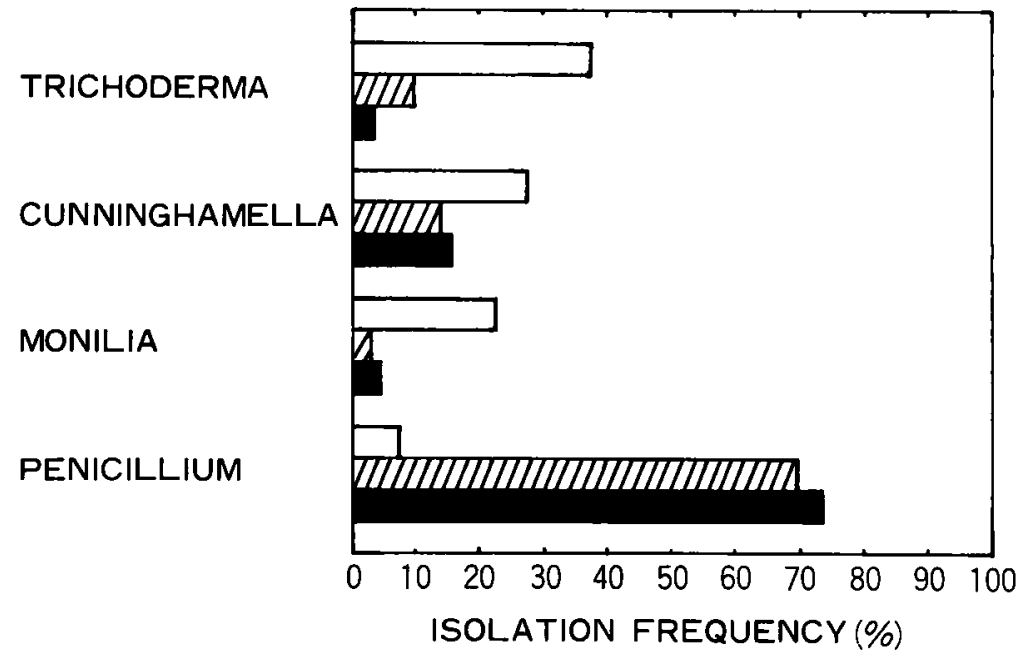

Fig. 1. The dominant fungi in the pasteurized soil stored for 21 days (blank bars), 121 days (oblique-lined bars) and 267 days (solid bars) in the wooden box.

\section{Growth of strawberries grown in the pasteurized soil}

Strawberry seedlings grown in the potted pasteurized soil (Fig. 4) set in the field were larger than those in the potted natural soil in size, heavier in fresh weight, and more numerous in the number of roots, and less in the rate of diseased roots (Fig. 5) in three 
separate experiments (Table 1). The grand average weight per plant was $15.5 \mathrm{~g}$ in the former vs. $8.7 \mathrm{~g}$ in the latter, and the healthy root rate was $46.8 \%$ vs. $28.3 \%$. In the paper-bagged soil experiments, no differences were observed between these two soils (Table 1).

Table 1. Growth of potted or paper-bagged strawberry seedlings ${ }^{2}$ ) from unrooted runners in natural (N) or pasteurized soil (P) set in the field of the Institute at Nishigahara

\begin{tabular}{|c|c|c|c|c|c|c|c|c|c|c|c|c|c|}
\hline \multirow{3}{*}{ Treatment } & \multirow{3}{*}{$\begin{array}{l}\text { Period and } \\
\text { days from } \\
\text { treatment }\end{array}$} & \multirow{2}{*}{\multicolumn{2}{|c|}{$\begin{array}{l}\text { Total } \\
\text { weights } \\
\text { (g) }\end{array}$}} & \multirow{2}{*}{\multicolumn{2}{|c|}{$\begin{array}{l}\text { Leaves } \\
\text { per plant } \\
\text { (no.) }\end{array}$}} & \multirow{2}{*}{\multicolumn{2}{|c|}{$\begin{array}{l}\text { Petiole } \\
\left.\text { length }^{\mathrm{b}}\right) \\
\text { (cm) }\end{array}$}} & \multicolumn{4}{|c|}{ Leaflet $^{\mathrm{c}}$} & \multirow{2}{*}{\multicolumn{2}{|c|}{$\begin{array}{c}\text { Healthy } \\
\text { roots } \\
(\%)\end{array}$}} \\
\hline & & & & & & & & \multicolumn{2}{|c|}{$\begin{array}{l}\text { Length } \\
\text { (cm) }\end{array}$} & \multicolumn{2}{|c|}{$\begin{array}{l}\text { Width } \\
(\mathrm{cm})\end{array}$} & & \\
\hline & & $\overline{\mathrm{N}}$ & $\mathrm{P}$ & $\mathrm{N}$ & $P$ & $\bar{N}$ & $\vec{P}$ & $\mathrm{~N}$ & $\bar{P}$ & $\bar{N}$ & $\mathbf{P}$ & $\overline{\mathbf{N}}$ & $\vec{P}$ \\
\hline \multicolumn{14}{|l|}{ Potted : } \\
\hline 1 & $\begin{array}{c}5 / 12-9 / 26 \\
(137)\end{array}$ & 11.1 & 18.5 & 4.0 & $5.0^{* *}$ & 10.5 & 9.5 & 5.3 & 6.0 & 4.5 & 5.0 & 27.9 & 39.3 \\
\hline 2 & $\begin{array}{c}5 / 24-10 / 5 \\
(134)\end{array}$ & 7.7 & 13.1 & 4.1 & 4.9 & 7.9 & 9.1 & 4.4 & $5.3^{k *}$ & $*_{3.6}$ & $4.4^{* *}$ & 29.6 & 47.8 \\
\hline 3 & $\begin{array}{c}6 / 3-10 / 13 \\
(132)\end{array}$ & 8.6 & $17.3^{*}$ & 5.0 & 5.3 & 9.7 & 10.0 & 4.8 & $5.5^{*}$ & *3.9 & $4.6^{* *}$ & 27.3 & 53.2 \\
\hline \multicolumn{14}{|l|}{$\begin{array}{l}\text { Paper- } \\
\text { bagged : }\end{array}$} \\
\hline 1 & $\begin{array}{c}6 / 13-10 / 30 \\
(139)\end{array}$ & 11.6 & 11.4 & 6.0 & 6.2 & 6.9 & 7.5 & 5.3 & 5.3 & 4.3 & 4.3 & 26.2 & 34.7 \\
\hline 2 & $\begin{array}{c}6 / 19-10 / 30 \\
(133)\end{array}$ & 11.1 & 11.5 & 5.8 & 6.2 & 6.6 & 7.0 & 5.0 & 5.4 & 4.0 & 4.3 & 29.8 & 38.7 \\
\hline
\end{tabular}

a) Data represent averages of three to seven replicates. The seedlings in the pasteurized soil were sometimes significantly different in growth than those in natural soil at $P=0.01\left(^{* *}\right)$ and $P=0.05\left(^{*}\right)$.

b) Data are averages of the largest four petiole lengths of each plant.

c) Data are averages of longest and widest portion of the three leaflets of the largest four leaves of each plant.

\section{Fungi associated with the roots}

Strawberry roots grown in the potted pasteurized soil and field soil yielded 28 and 30 fungus genera, respectively when 544 and 577 isolates of fungi were examined, and among these, 21 genera were found commonly in both treatments. Twelve fungus genera were always recovered with over $3 \%$ isolation frequency from the roots in either or both of the pasteurized soil, and / or the field soil in three separate experiments (Fig. 2). Predominance of Penicillium spp. in the pasteurized soil, and of Fusarium and Rhizoctonia spp. in the field soil was conspicuous in the potted soil experiments (Fig. 2,3). Especially Rhizoctonia spp. were found associated with an average of $24.2(16.2-29.3) \%$ of the root segments of strawberries in the field soil, whereas $7.2(4.1-12.8) \%$ in the pasteurized soil.

Strawberry roots in the paper-bagged pasteurized soil and the field soil yielded 17 and 24 genera, respectively, when 189 and 194 isolates were examined, and among these, 15 genera were found commonly in both soils. Rhizoctonia spp. were predominant with the isolation frequencies of 37.6 and $20.1 \%$ in both treatments (Fig. 3). Three genera, Aspergillus, Dactylella, and Hainesia were recovered from the plants grown in the paperbagged soil, but not from the potted soil.

Fungi isolated from strawberry roots in this study were quite similar to those recorded 


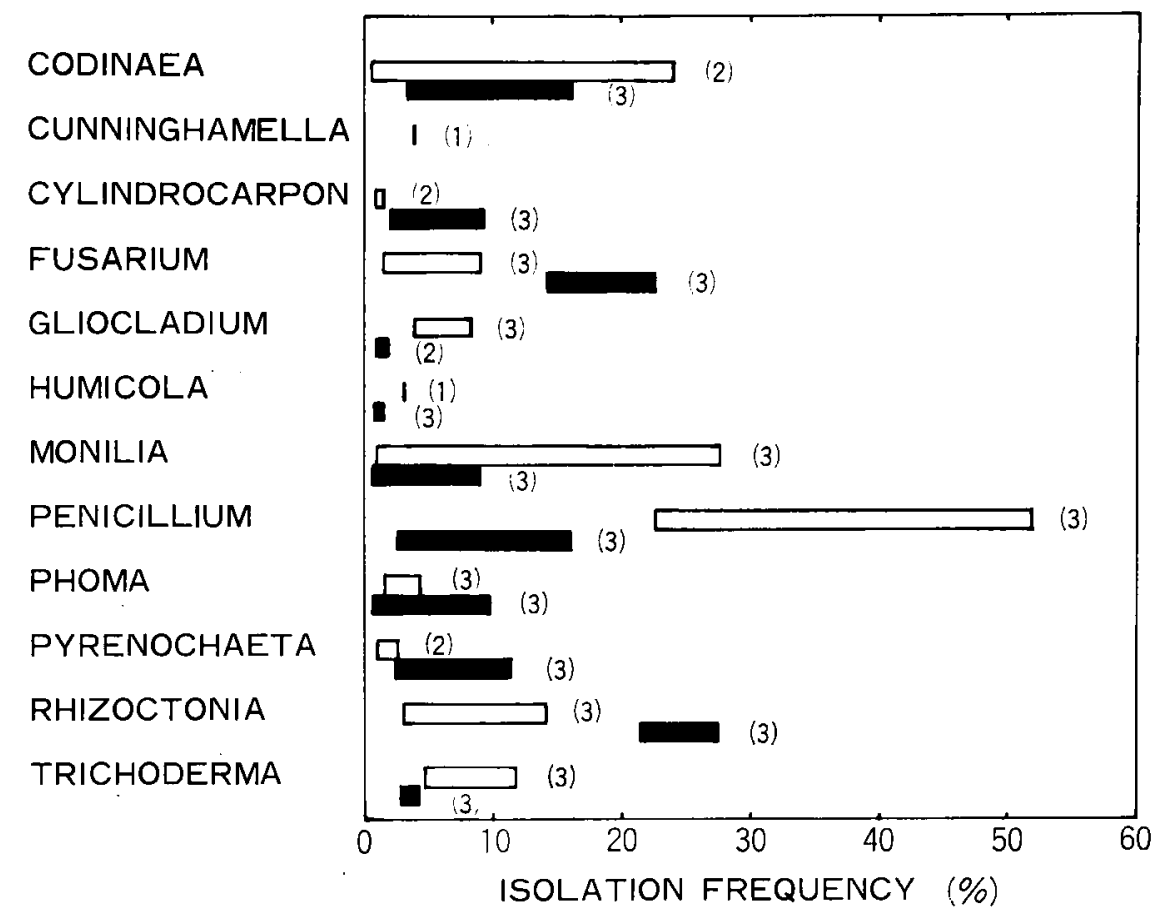

Fig. 2. Dominant fungi (over $3 \%$ in isolation frequencies in either or both treatments in each of three separate experiments) associated with strawberry roots grown in the potted pasteurized soil (blank bars), and the potted natural soil (solid bars), and their isolation frequencies. The figures in the parentheses indicate the number of frequency of the experiments with the recovery of the respective fungi in all of three separate experiments.

in the previous studies ${ }^{11,13)}$ in Japan except nine genera, namely Aspergillus, Botryotrichum, Hainesia, Periconia, Pleiochaeta, Syncephalastrum, Tetraploa, Trichurus, and Ulocladium.

Fungi recovered from the roots were rather similar to those from the soils except about 20 genera. For example, 11 genera that were recovered only from the roots were alphabetically Centrospora, Chrysosporium, Codinaea, Curvularia, Oideodendron, Periconia, Pleiochaeta, Rhinocladiella, Rhizoctonia, Robillarda, Tetraploa, Torula, and Ulocladium, and 10 genera only from the soil were Histoplasma, Monocillium, Oedocephalum, Papulaspora, Pithomyces, Sarcinella, Stemphylium, Trichothecium, Verticillium, and Volutella.

\section{Antagonism of candidate antagonists from the pasteurized soil to test organisms}

Various degrees of antagonism to test organisms were demonstrated in several in vitro tests conducted under different environmental conditions using the fungi recovered from the pasteurized soil. When a candidate antagonist and a test organism were inoculated at the same time, inhibition zones were formed by a few candidate isolates to Rhizoctonia solani, one of test organisms at $20 \mathrm{C}$, and rarely at $26-28 \mathrm{C}$ two days after treatment. However, a candidate antagonist preinoculated 1-3 days earlier than the test organism formed inhibition zones between both organisms at 20-28 C. Typical data from repeated 


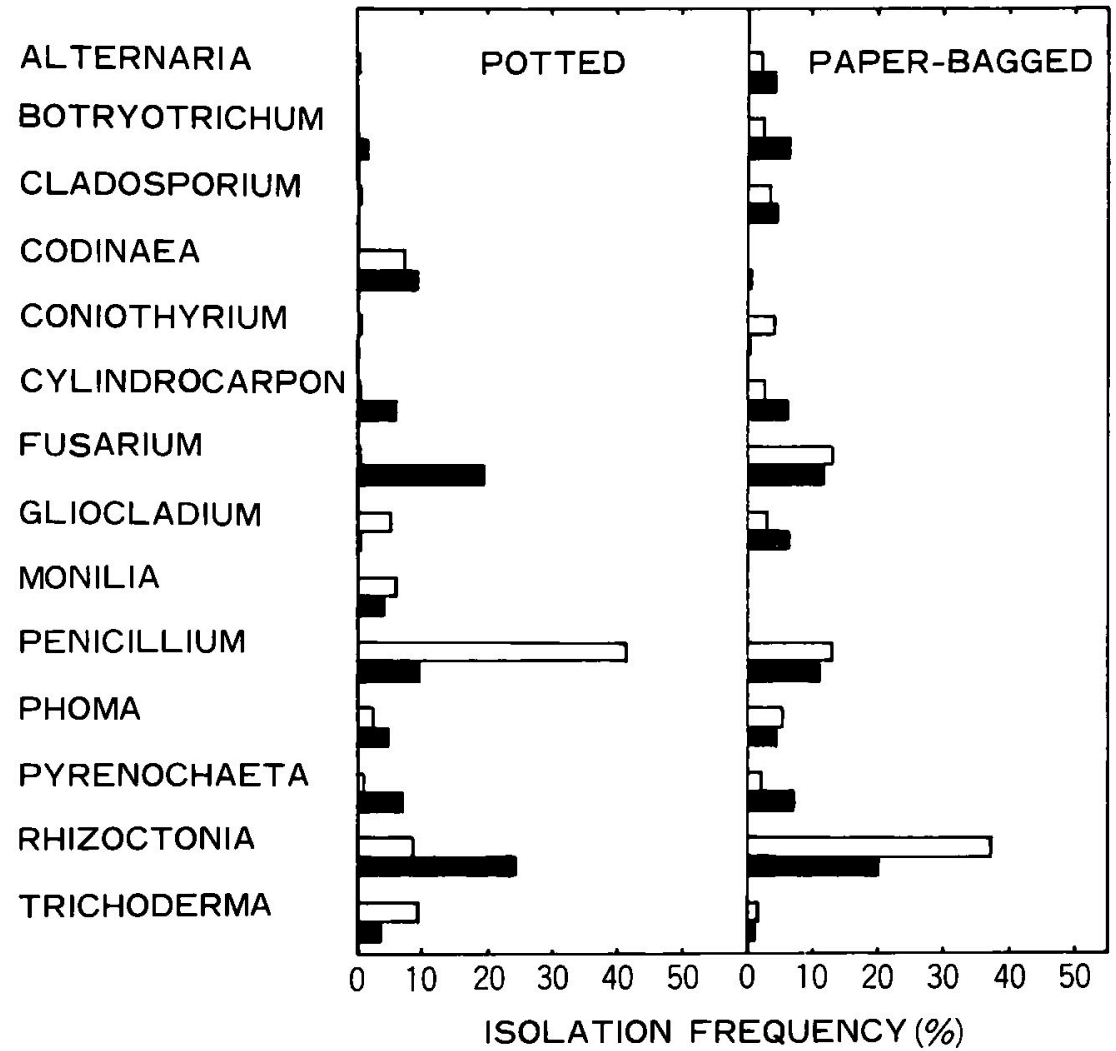

Fig. 3. Dominant fungi (over $3 \%$ in isolation frequencies in each or both treatments in summarized data) associated with strawberry roots grown in potted or paper-bagged pasteurized soil (blank bars), and natural soil (solid bars), and their isolation frequencies.

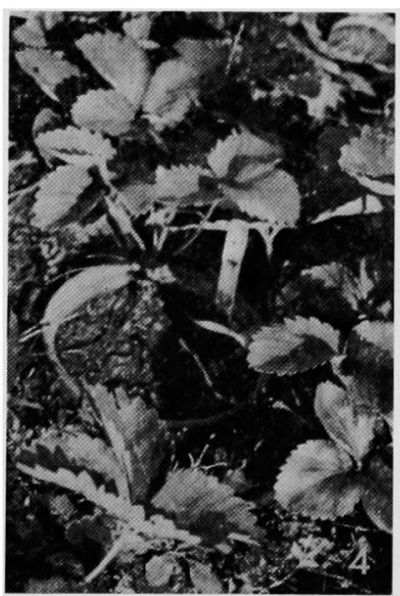

Fig. 4. Growth of strawberry seedlings under natural environmental conditions 132 days after unrooted runners were struck in the potted soil in the field. Note a clay pot buried in soil.

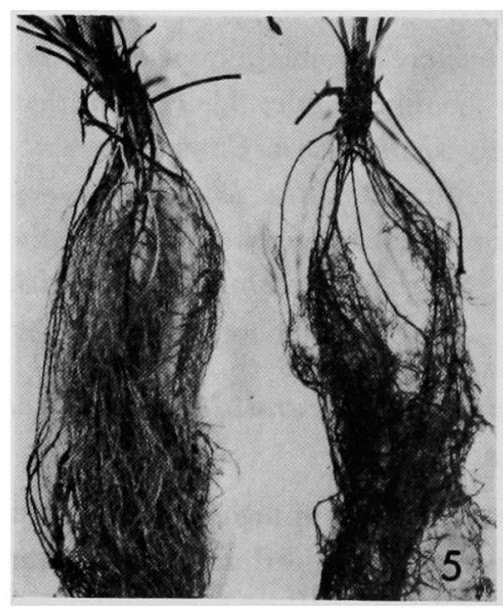

Fig. 5. Roots of strawberry plants grown in the potted pasteurized (left) and natural soil (right) 132 days after treatment. 
Table 2. Antagonistic effects ${ }^{\mathrm{a})}$ of Penicillium spp. isolated from the pasteurized soil as determined by colony radius of test organisms in single (control) or dual culture, percentage inhibition of rate of radial growth, and width of the inhibition zones

\begin{tabular}{|c|c|c|c|c|c|c|}
\hline \multirow[b]{3}{*}{ Isolates } & \multicolumn{6}{|c|}{ Test organism } \\
\hline & \multicolumn{3}{|c|}{ Pythium splendens } & \multicolumn{3}{|c|}{ Rhizoctonia solani } \\
\hline & $\begin{array}{l}\text { Colony } \\
\text { radius } \\
\text { (mm) }\end{array}$ & $\begin{array}{c}\text { Inhibition } \\
\text { of growth } \\
\text { rate } \\
(\%)\end{array}$ & $\begin{array}{l}\text { Width of } \\
\text { inhibition } \\
\text { zone } \\
(\mathrm{mm})\end{array}$ & $\begin{array}{l}\text { Colony } \\
\text { radius } \\
(\mathrm{mm})\end{array}$ & $\begin{array}{l}\text { Inhibition } \\
\text { of growth } \\
\text { rate } \\
(\%)\end{array}$ & $\begin{array}{l}\text { Width of } \\
\text { inhibition } \\
\text { zone } \\
\text { (mm) }\end{array}$ \\
\hline Control & 32.7 & 0 & 0 & 31.6 & 0 & 0 \\
\hline $78-2601$ & 7.0 & 78.6 & 10.0 & 11.2 & 64.6 & 6.0 \\
\hline $78-2604$ & 12.3 & 62.4 & 3.3 & 13.0 & 58.9 & 1.0 \\
\hline $78-2605$ & 14.8 & 54.7 & 0.7 & 12.7 & 59.8 & 1.3 \\
\hline $78-2606$ & 14.7 & 55.0 & 2.0 & 12.3 & 61.1 & 3.0 \\
\hline $78-2607$ & 6.7 & 79.5 & 9.0 & 13.0 & 58.9 & 0.7 \\
\hline $78-2608$ & 7.0 & 78.6 & 11.0 & 15.7 & 50.3 & 0 \\
\hline $78-2609$ & 8.3 & 74.6 & 7.3 & 14.2 & 55.1 & 0 \\
\hline $78-2610$ & 11.3 & 65.4 & 5.0 & 7.3 & 76.9 & 7.3 \\
\hline $78-2611$ & 7.3 & 77.7 & 10.0 & 14.2 & 55.1 & 0 \\
\hline $78-2612$ & 15.8 & 51.7 & 0.5 & 10.7 & 66.1 & 3.0 \\
\hline
\end{tabular}

a) Penicillium spp. were preseeded by a prick inoculation $72 \mathrm{hr}$ earlier than test organisms, and results on $P$. splendens and $R$. solani were obtained in 24 or $48 \mathrm{hr}$ after treatment. respectively. Data are averages of two replications, three plates per replication.

experiments are shown in Table 2.

The growth of any test organism was inhibited in contact with a candidate antagonist, intermingling each other in both mycelia, by the coverage of the test organisms with isolates of Trichoderma spp. and Cunninghamella echinulata used as candidate antagonists, or due to antibiosis evidenced by inhibition zone formation (Fig. 6,7). Test organisms at the edge of inhibition zones were disintegrated in the apical parts of hyphae, releasing protoplasmic contents, especially in dual culture with Penicillium spp. on PDA plates (Fig. 8).

\section{Discussion}

The potted strawberry seedlings struck from the runners in the pasteurized soil set in the field grew better with lower rate of discolored roots than those in the potted natural soil in the same field about 130 days after treatment. Potential soilborne

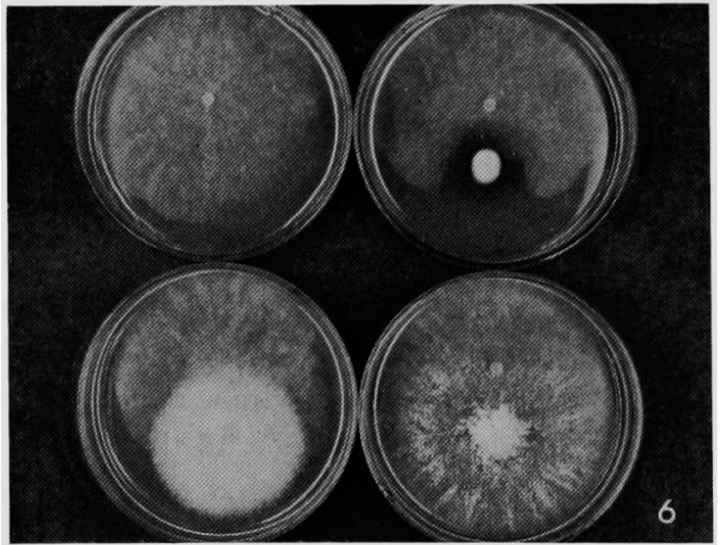

Fig. 6. Antagonism of candidate antagonistic fungi isolated from the pasteurized soil to Pythium splendens on PDA in plates. Pythium splendens in single culture served as control $24 \mathrm{hr}$ after inoculation (upper left), and Penicillium sp. (upper right), Cunninghamella echinulata (lower left), or Trichoderma sp. (lower right) in dual culture with $P$. splendens. Candidate antagonists were preinoculated for $24 \mathrm{hr}$ when dualcultured with $P$. splendens. 


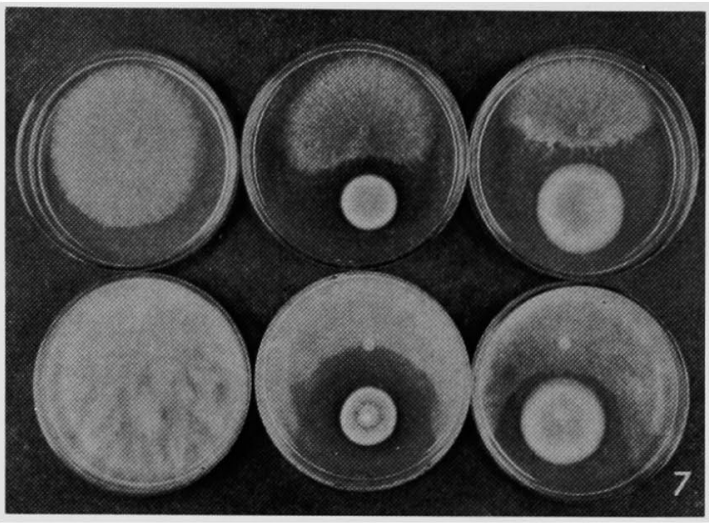

Fig. 7. Antagonism of Penicillium spp. to Pythium splendens and Rhizoctonia solani. From left to right: $R$. solani (upper row) or $P$. splendens (lower row) served as controls in single culture $48 \mathrm{hr}$ after inoculation; Penicillium sp. (isolate no. 78-2601); and Penicillium sp. (78-2610) in dual culture with $R$. solani (upper row) or $P$. splendens (lower row). Penicillium spp. were preinoculated for $72 \mathrm{hr}$ when dual-cultured with test organisms.

Fig. 8. Disintegrated hypha of Pythium splendens (left), and Rhizoctonia solani (right) near the inhibition zone in dual culture with Penicillium sp. (isolate no. 78-2601) $48 \mathrm{hr}$ after treatment.
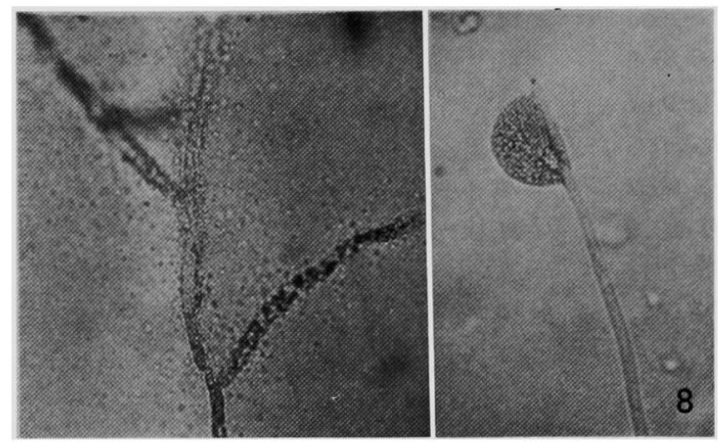

pathogens including Rhizoctonia solani may be concerned with the poorer growth in the latter although some other factors, namely the physical properties of soil, the solubility of nutrients, and also changes in the soil microflora and fauna may be more important.

However, in the paper-bagged soil experiments, no differences were observed in growth rate between the pasteurized and natural soil.

Differences in these two experiments may be attributable to the easiness of contamination of plant roots with microorganisms including potential soilborne plant pathogens from the field soil in the early stage of rooting, because the paper bags set in the field were easily disintegrated within a month after treatment.

Fungus floras associated with the roots were very different between the potted pasteurized soil and the potted natural soil. Especially, Rhizoctonia, Fusarium, Cylindrocarpon, and Pyrenochaeta were more frequently isolated in the former soil, but Penicillium and Trichoderma were more in the latter. However, the fungus floras were not conspicuously different between the paper-bagged pasteurized soil and the paper-bagged natural soil, indicating swift unification of the fungus floras in the treated soil with the field soil (Fig. 3 ).

No inoculation experiments using strawberry root isolates were conducted in this study, but the frequent isolations of potential soilborne plant pathogens like Rhizoctonia solani may be responsible for the poorer growth in the potted natural soil. In addition, abundance of Penicillium and Trichoderma in the potted pasteurized soil might be responsible for the prevention of the ingress of potential soilborne plant pathogens onto the host roots as shown in the model experiments on antagonism of Penicillium spp. to the test organisms.

The growth of plants in the pathogen-free soil from virgin soil or prepared from 
autoclaved or fumigated soil is better as a rule under greenhouse conditions. In addition, there are examples of successful cultivation in growing young plants in such pathogen-free soil locally set in the fields naturally infested with given soilborne plant pathogens ${ }^{2,7}$. These successes are explained as reduction of susceptibility of plants to the pathogens after maturity when grown in the local virgin soil ${ }^{7}$, or slowness of distribution of the pathogen through soil ${ }^{2}$. In addition, antagonistic organisms like Penicillium spp. might be active against soilborne plant pathogens penetrating into the host roots as indicated in this study, and the work done by Kommedahl and Windels ${ }^{8}$.

Furthermore, suppresiveness of natural soil or recontaminated steam-sterilized soil to the artificially infested soilborne plant pathogens like Gaeumannomyces graminis (Ophiobolus graminis) and Fusarium roseum 'Avenaceum' was shown to be due to the activities of Trichoderma viride, Mucor and Penicillium spp. ${ }^{9,10)}$. Thus, it may be possible to obtain better growth in various plants including strawberry by causing the changes in soil microflora partially by replacing field soil with the natural virgin soil or the pasteurized soil.

\section{Literature cited}

1. Baker, K.F. (1970). In Root Diseases and Soil-borne Pathogens (Toussoun et al. eds.) Univ. Calif. Press, Berkeley and Los Angeles, pp. 234-239.

2. Burke, D. W. (1965). Phytopathology 55 : 1188-1191.

3. Hildebrand, A. A. (1934). Can. J. Res., C, $11: 18-31$.

4. Hildebrand, A. A. and West, P. M. (1941). Ibid. C, 19: 183-198.

5. Johnson, J. (1946). Soil Sci. $61: 83-92$.

6. Katznelson, H. and Richardson, L. T. (1948). Sci. Agr. 28: 293-308.

7. Ko, W. (1971). Phytopathology $61: 780-782$.

8. Kommedahl, T. and Windels, C. E. (1978). Ibid. 68: 1087-1095.

9. Lin, Y. S. and Cook, R. J. (1979). Ibid. $69:$ 384-388.

10. Ludwig, R. A. and Henry, A. W. (1943). Can. J. Res., C, $21: 343-350$.

11. Watanabe, T. (1977). Trans. mycol. Soc. Japan 18: 251-256.

12. Watanabe, T. and Inoue, S. (1977). Ann. Phytopath. Soc. Japan 44 : 105 (Abstr. in Japanese).

13. Watanabe, T., Hashimoto, K. and Sato, M. (1977). Phytopathology $67: 1324-1332$.

14. West, P. M. and Hildebrand, A. A. (1941). Can. J. Res., C, 19 : 199-210.

\section{和 文摘 要}

畑の一部に入れた病原菌非污染土堙でのイチゴの生育と根部の糸状菌相

\section{渡辺恒雄・井上昭司}

イチゴ烟に埋めこんだ病原菌非污染土と無殺菌の畑土入りのポットにイチゴのランナーを根つかせ，自然 条件下での生育を移植後 132〜137 日後に 比較したところ，前者のほらが後者よりも良好な生育を示した。 根部の釆状菌相を調べところ，前者からは28属の手状菌（未同定菌は除く）が検出され，Penicillium と Trichoderma 属菌の分離頿度が高かったが，後者からは30属が検出され，Rhizoctonia と Fusarium 属菌が， 高頻度で分離された。病原菌非污染土でのイチゴの生育の良さは，根部の釆状菌相の差異とも関係があり， 土镶伝染病原菌などによる根部の被害がPenicillium 属菌などによる拮抗作用の結果軽減されたためではな いかと推测される。 